\title{
Three Unpublished Stone Monuments Returned Homeland
}

\section{ثلاثة قطع اثرية حجرية غير منشورة عادت الى الوطن}

\author{
Mohamed A. El-Tonssy \\ Professor of Ancient Archeology- Faculty of Arts Helwan University-Cairo-Egypt \& Taif University- \\ Kingdom of Saudi Arabia. \\ tonssy55@gmail.com
}

Ali Ahmed Ali

Doctor of Ancient Archeology Ministry of Tourism and Antiquities

Waj_ib@yahoo.com

محمد عبدربه التونسي

استاذ الاثار والحضارة القديمة بكلية الآداب بجامعتي حلوان بالقاهرة والطائف بالمملكة العربية السعودية

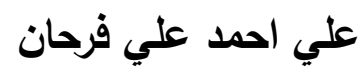

دكتوراة في الآثار المصرية القديمة - وزارة السياحة والآثار

\section{Abstract:}

Publication of three characteristic inscribed stone objects that were returned from Europe between years 2015 and 2016. The first stone piece represents a Late Period sandstone votive stela. The second object appears as a survived part of a wall that came from a lost temple built in Mangabad at Asyut. It is displayed in Sohag regional museum. The third object represents an attractive double black statue that returned from Belgium. The first and the third objects are currently exhibited in Kafr El-Sheikh regional museum.

Keywords:

Double statue, Limestone votive stela, Asyut lost temples, Mangabad lost temple, God Wepwawet, King Seti I monuments, Temple of Seti I at Asyut, Sohag Museum, Kafr El-Sheikh Museum.

تضضمن الدراسة نشر ثلاثة قطع حجرية غير منشورة تمثل الاولى منها لوحة حجرية نم ضبطها بمطار شارل ديجول

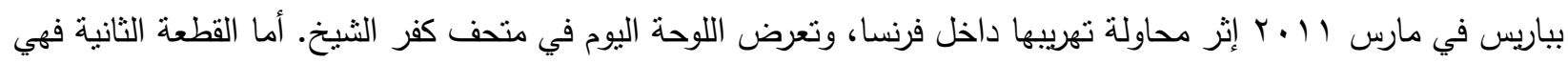
عبارة عن لوحة جدارية من معبد لم يكتثف يؤرخ بعصر الدولة الحديثة وبالتحديد عهد الملك سيتي الاول وقد تم استعادتها من

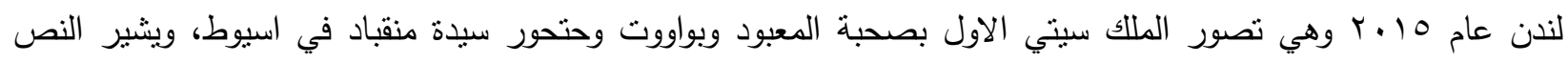
المصاحب للمنظر الى مدينة منقباد في محافظة اسيوط في مما يشير الى وجود معبد مفقود هناك شيده الملك سيتي الأول ولم يتم العثور عليه حتى الان، وتعرض القطعة اليوم في متحف سوهاج. والقطة الثالثة عباره عن تمثال حجري مزدوج لعله يمنل

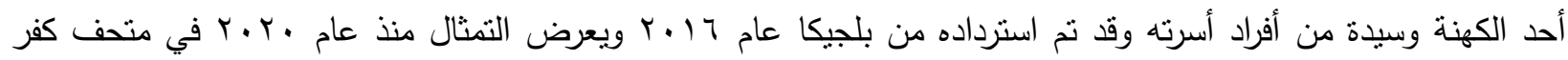

الكلمات الدالة:سيتي الأول؛ معبد سيتي الاول في اسيوط؛ المعبود وبواووت؛ لوحة حجرية؛ مدينة منقباد؛ تمثال مزدوج؛ متحف

$$
\text { كفر الثيخ؛ متحف سوهاج. }
$$




\section{Introduction:}

After the Egyptian Revolution in 2011, these stone monuments were looted and smuggled out of Egypt to find a marketable market in Europe. Before five years ago the Egyptian authorities succeeded in retrieving these monuments from Europe. Thus, these three wonderful artifacts are just a few of hundreds of antiquities stolen by multinational trafficking rings ${ }^{1}$.

The double black statue was found with a Belgian dealer together with another one that was discovered in Memphis cemetery by the teamwork of the inspectorate of Memphis and then it was stolen from the local storerooms. However, all of these stone monuments were actually outcomes from illegal excavations.

\section{1- The Votive Stela of Pth- ir-di.s: [pl.1,fig.1].}

This round-topped votive stela returned back to Egypt from Paris in April 2015 to be displayed in the regional museum of Kafr El-Sheikh in November 2020.

\section{A- Description:}

This limestone stela is well preserved except for the right lower part which is partly missing.it measures $57 \mathrm{~cm}$ in height, $30 \mathrm{~cm}$ in width and 6.5 in thickness. The upper register shows the owner of the stela who is called "Pth-ir-di.s" standing before Osiris and Isis. He wears a long tonic with an apron tied around his waist, his head was lost. The owner is depicted in the front of Osiris offering the two " $n w$ "vessels" 2.

The god Osiris is depicted seated on a low back chair before an offering table with his normal mummiform wearing a broad collar, and counterpoise, an Atef-crown with a cobra, and a divine beard. His two hands are shown crossed on the chest; the left hand holds the $h k 3$ scepter while the right one holds the $N h h$ flail. Isis is shown standing behind Osiris, her right hand holds the $n h$ amulet while the left hand holds the scepter. The Goddess Isis wears the tripartite wig with the sun disk flanked by the

${ }^{1}$ Unfortunately, many of Egyptian antiquities were illegally smuggled out of the country during this revolution. The Ministry of Antiquities closely cooperated with the Egyptian Ministry of Foreign affairs to recover these looted monuments. It is unclear, as usual, how or when all of these artifacts were stolen from Egypt. In the end, more than a thousand smuggled monuments have been returned back to the country so far.

${ }^{2}$ JANSSEN, J. Commodity Prices from the Ramessid Period, Leiden, 1975, 421-422. 
two horns and a long tight dress. The upper register of this round-topped stela is decorated with a popular winged sun disc.

\section{B-Text:}

\section{- The upper register:}

Above the main scene of the stela at the upper register, the name of Osiris and Isis were inscribed. It is written from the right side and reads:

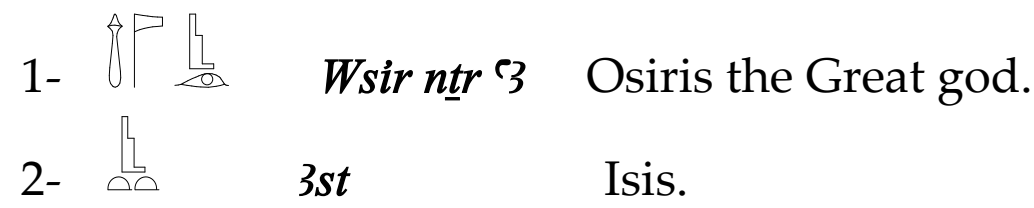

\section{- The lower register:}

The lower register of the stela is inscribed with more than five horizontal lines of hieroglyphs inscriptions. Three of which are still in a good state of preservation. Unfortunately, two hieroglyphs lines at least were erased on the lowermost part of the stela.

The remaining three columns read as follows:

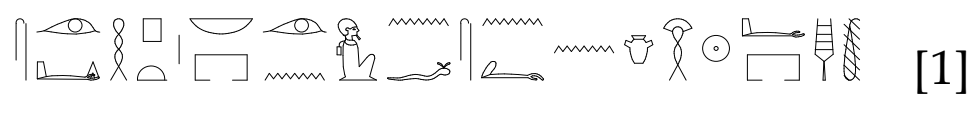

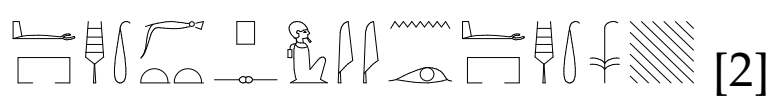

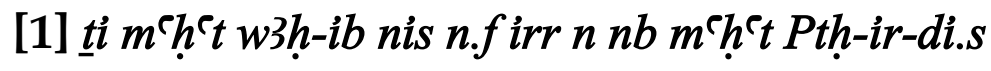

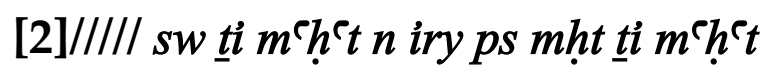

[3]///// imntt pwr hr ps i3btt pw r ḥr

[1] This tomb(stela) (a) is dedicated to please the lord of this tomb Pth-ir-di.s (b).

[2] ///// This tomb is for the owner where the cake backed (in) the tomb.

[3]///// (c) The west is on the front of (his) (d) face and the east is on the front of (his) face. 


\section{C-Comment:}

(a) The word $m^{\text {' }} h^{\complement} t$ was attested to give the meaning of "the tomb" from Old Kingdom texts ${ }^{3}$. But in the Late Egyptian texts, it has had the meaning of tomb-stela or the slab ${ }^{4}$. Moreover, the sun disc sign which was inscribed in this word was used as a determinative for the meaning of the tomb as if the first place of rebirth like the shining sun forever ${ }^{5}$.

(b) The owner's name of the stela Pth-ir-di.s was widely used, according to Ranke, from the Middle Kingdom to the Late Period ${ }^{6}$.

(c) The normal sign of the word imntt was scratched from the beginning of the word due to the damage on the lower right side of the stela ${ }^{7}$.

(d) The meaning often seems to refer to the deceased who will receive the sun rays in his netherworld at his tomb ${ }^{8}$.

\section{2-King Seti I's Stone Block: [pl.2, fig.2].}

In December 2015, after intensive efforts from the Ministry of Antiquities with international Interpol for nine months, this remarkable stone block was acquired from London.

\section{A-Description:}

This stone block has an irregular square shape, the left side was completely broken. The block contains nine vertical columns of wellpreserved hieroglyphs text that inscribed on its upper part and above the main scene. The main scene depicts the king Seti 1st twice together with the local deities of Asyut Hathor and Wepwaut ${ }^{9}$. It is worth mentioning that Seti 1's relief decorations are strongly famous for their high quality and finesse details. This artistic criterion became a distinctive technique at the

\footnotetext{
${ }^{3}$ ERMAN, \& GRAPOW, (EDS.): Wb II, 4 (7-14).

${ }^{4}$ LESKO, L., A Dictionary of Late Egyptian, Providence, RI: B.C. Scribe Publications, 2002, vol.1, 182.

${ }^{5}$ The sun disc sign is used as a normal determinative for the word $\boldsymbol{m}^{\boldsymbol{}} \boldsymbol{h} \boldsymbol{h}^{\mathrm{t}} \boldsymbol{t}$ with the meaning of the tomb in Late Egyptian texts: review Gardiner, A., Late Egyptian Stories, Bruxelles, 1932, 5,2-52.

${ }^{6}$ RANKE, H., Die Ägyptischen Personennamen, Glückstadt, 1935, vol., I, 138 -16-17.

${ }^{7}$ Review: ERMAN, \& GRAPOW, (EDS.): Wb I,87-1-13.

${ }^{8}$ Commonly, the stelae inscribed with spell 15 of the Book of the Dead referring to Osiris-Re cycle of rebirth: review Allen, G., The Book of the Dead, or Going Forth by Day, London 1974, 12-26.

${ }^{9}$ For more details about the role of god Wepwaut at Asyut: review, Wells, E., «Display and Devotion: A Social and Religious Analysis of New Kingdom Votive Stelae from Asyut», UCLA Electronic Theses and Dissertations, California 2014; DuRISCH, N., «Culte des Canidés à Assiout: Trois Nouvelles Stèles Dédiées à Oupouaout», BIFAO 93, 1993, 205-221.
} 
Early Nineteen Dynasty, particularly from the beginning of King Seti 1's reign ${ }^{10}$.

The first scene to the right corner depicts the king Seti 1st standing before the goddess Hathor Lady of Mangabad at Asyut. The king wears the hprš- crown with a cobra on his head 11 , the lower part of his body is unfortunately destroyed. Hathor is depicted with her well-known Hathorcrown, giving the Mnit and ' $n h$ signs to the king with her left hand.

In the second scene to the left, the local god of Asyut Wepwaut is depicted with the head of a jackal standing behind a remaining figure of the king. The rest part of the king's figure shows remains of the upper part of the royal crown with the sun disk, Nhh-flail, and the Wsht-necklace ${ }^{12}$. Traces of blue and dark red paints could be seen in different places of human figures.

\section{B-Text:}

The text above the scene of the king contains nine vertical columns of inscriptions. It was curved in two different directions. The first text above the king's head and the god Wepwaut virtually begins from left to right while that one which is situated above the head of the goddess Hathor begins from right to left. Two royal cartouches of king Seti $1^{\text {st }}$ are carefully carved in a high standard of craftsmanship. All the text signs are carefully written with internal details ${ }^{13}$.

\footnotetext{
10 For more elaboration review, BRAND, P., The Monuments of Seti 1 and Their Historical Significance: Epigraphy, Art Historical and Historical Analysis, University of Toronto, Canada, 1998, 26-39.

${ }_{11}$ Many scholars widely refer to this crown as the blue one, and it is attested at least from the Eighteen Dynasty: review DAVIES, V., «The Origin of the Blue Crown», JEA 68, 1982, 70-74, FIGS.4-14.

12 The sun disk atop the remnants of the crown strongly affirms that it was the Atef crown, not the Khepresh one which usually consists of uraeus, ram horns, feathers and sun disk: see Collier, S., «The Khepresh Crown of Pharaoh», A Journal of African Studies 21, 1-2, 1993, 137-155.

13 The great accuracy and detail in curving hieroglyphs writing and scenes are prototypes for all monuments of Seti 1 st.: review CALVERLEY, M., The Temple of King Sethos I at Abydos, Volume III: The Osiris Complex, London, 1938.
} 


\section{-The Right Text:}

The text inscribed atop the figure of the king, it reads as follows:

(4)

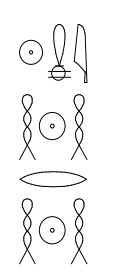

(3)

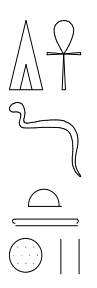

(2)

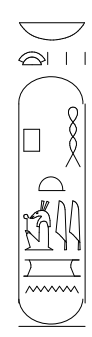

(1)

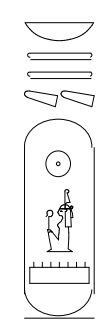

[1] $n b t 3 w y\left(M n m 3^{\top} t R\right)$.

[2] $n b h^{\complement} w$ (Sty mry $n$ Pth).

[3] di ' $n h \underline{d} \underline{d t} s p . s n$

[4] mi Re nḥh $r n h h$.

[1] Lord (e) of the two lands (Men-mat-Re) ${ }^{14}$.

[2] Lord of diadems (Seti beloved of Ptah) ${ }^{15}$.

[3] Given life ${ }^{(f)}$ twice forever and ever.

[4] Like Re forever and ever.

-The Middle Text:

The middle text contains only two vertical columns of inscriptions as follows:

[1] $H t-h ̣ r n b t$

$(2)$

(1)

\section{[2] $M \underline{d} d n$}

[1] Hathor (g) the Lady

[2] of Mangabad (h).

${ }_{14}^{14}$ VON BECKERATH,Handbuch der Ägyptischen Königsnamen, MÄS 20, Mainze : P. Von Zabren, 1984, 88$89,234-236$.

${ }_{15}$ KITCHEN, K., Ramesside Inscriptions, Historical and Biography, 1, Oxford, 1975, 7-13, 14-9, 17-5; VON BECKERATH, Königsnamen, 236, E1-E6. 


\section{-The Left Text:}

This part of text is written in three vertical lines. The left side of the royal cartouche and the head of geese sign were erased. However, the text reads as follows:

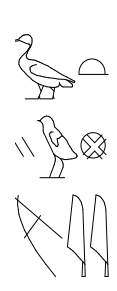

(2)

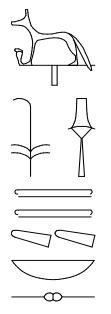

(1)

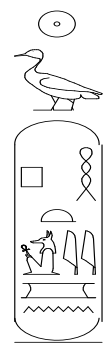

[1] s3 $R^{e}($ Sty mry $n$ Pth $)$.

[2] $=(m r y) W p-w 3 w t \check{S} m^{\top} w$ shm $t 3 w y n b=$

$[3]=S 3 w t$.

[1] The son of Re (Seti beloved of Ptah).

[2] =(Beloved of) Wepwaut of upper Egypt, Controller of the two Lands

(i), Lord of $=$

[3] Asyut (j) .

\section{C-Comment:}

(e) The left part of the " $n b$ sign" is badly destroyed, however, it is easily readable.

(f)Regarding the formula criteria of the commonly used form " $d i{ }^{~} n h$ mi $R^{r}$ $\underline{d} t$ "in Seti 1 st monuments at Karnak, it could be confirmed that the correct

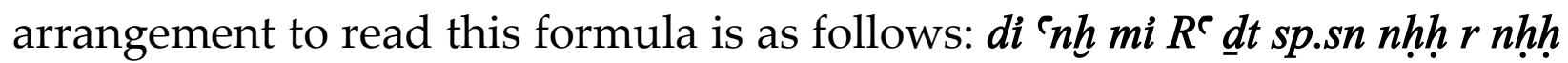
which often have had translated as follows: Given life like Re forever twice forever and ever ${ }^{16}$.

(g) Mentioning the title of Hathor "Lady of Mangabad" in this block, clearly indicates that the goddess was worshiped with Wepwaut in a lost temple which was mostly built somewhere in the area around the town ${ }^{17}$.

16 This kind of cryptographic writing was attested from Eighteen Dynasty with regarding the intensively use in Seti 1st monuments especially at Karnak: review KITCHEN., Ramesside Inscriptions, 16-19, 33-5, 38-9, 12, 41-12.

17 This view is confirmed by bearing Hathor such title in numerous antiquities that came from Asyut dates back to different periods: review DURISCH, Culte des Canidés à Assiout, 213-214; DuQUESNE, T., «Hathor of Medjed», Discussions in Egyptology 54, 2002, 39-60. 
(h) The town of Mangabad is currently located to the north of Asyut province, three miles away from the city center ${ }^{18}$. It was an important religious sanctuary for the deities Hathor and Wepwaut ${ }^{19}$. Accordingly, this strongly supports the hypothesis of erecting a lost temple dating back to the reign of king Seti 1st which was probably dedicated to Wepwaut and Hathor in Mangabad at Asyut governorate 20 .

(i) The title of god Wepwaut "šm ${ }^{`} w$ ' $m-t 3 w y$ " was widely used from at least the First Intermediate Period onwards ${ }^{21}$.

(j)Asyut province is located more than 250 miles south of Cairo. It was known as the capital of the thirteenth Upper Egyptian nomes ${ }^{22}$. The local Jackal god of the city was Wepwaut whose temple more likely was built at Deir Dronka. The Old Egyptian toponym " s3wt "is still used in the Arabic language referring to the whole city. In the Ptolemaic and Roman times, the province was named "Lycopolis": " The Jackal Town" ${ }^{23}$.

\section{3-Double Statue of Wsr-Pth-wnn.f: [p1.3,4,5: fig.3-4].}

This remarkable small statue was exhibited together with another one in a private Belgian gallery of Antiquities. Ultimately, it was returned from Belgium in April 2016, after intensive efforts have been made by the Ministry of Antiquities. Currently, it is displayed in Kafr El Sheikh museum.

\section{A-Description:}

The statue is made from black basalt and measures $64 \mathrm{~cm}$ in height,38 $\mathrm{cm}$ in width. It is well preserved except for a small part on the right side of the base that is destroyed.

\footnotetext{
18 There were many feminine titles mentioned Hathor the lady of Mangabad like the chanters of Hathor at Mangabad whose name was Renennoutt Review for such examples, KAMAL, A., «Fouilles à Deir Dronka et à Assiout», ASAE 16, 1916, 87-102; GARDINER, A., Ancient Egyptian Onomastica, Oxford, 1947, vol.2, 68.

${ }_{19}$ GAuthier, H., Dictionnaire des Noms Géographiques Contenus dans les Textes Hiéroglyphiques, Caire Société Royale de Géographie d'Égypte, vol 3, 1926, 26; MONTET, P., «Les Tombeaux de Siout et de Deir Rifeh», kêmi 6, 1936, 134-135.

20 This view was deduced from this stone block and the two royal cartouches of the king Seti 1 st, it is more likely that the expected site on which this lost temple was built is frequently located at Deir Dronka in Asyut: review footnotes 33.

21 KAMAL, Fouilles à Deir Dronka et à Assiout, 92; LeITZ, C., Lexikon der Ägyptischen Götter und Götterbezeichnungen, Orientalia Lovaniensia Analecta 111, 2002, vol.2, 342-349; DUQUESNE, T., "Votive Stelae for Upwawet from the Salakhana Trove», Discussions in Egyptology, 48, 2000, 5-47; BARTA, W., «Aufbau und Bedeutung der Altagyptischen Opferformel», AgFo 24, 1968, 222 ff.

${ }^{22}$ GAUTHIER, Dictionnaire, vol.5, 3-4; GARDINER, Onomastica, 74.

${ }^{23}$ GARDINER, Onomastica, 74-75.
} 
It represents Weser-ptah-wennef standing with his two hands hang at his sides over a simple wrap-around robe. A belt is shown around his waist at the top of his robe. His two ears and eyes are detailed. Beside him, to his right, a lady is represented, probably his daughter, in a standing attitude in a skinny form. She wears a large plaited wig and a long transparent robe. Her face is sharply broad, and her two arms hang at her sides with an open fist. It is ridiculous that male and female traits on the faces of two statues are exactly the same. How the faces have been sculpted is actually an astonishing topic, one couldn't simply realize for whom this statue was sculpted. Therefore, this certainly indicates that the genetic origin of owners is definitely the same ${ }^{24}$.

The double statute stands against a rectangular back-slab reaching the shoulder of owners. It is connected with the stone pillar to form a technical single "L" shape together with the pedestal ${ }^{25}$.

\section{B-Text:}

The statue bears only two horizontal lines of inscriptions. All of which are inscribed on the pedestal of the statue. Most of the hieroglyphs signs are slightly cursory written without internal details ${ }^{26}$. The text of Weser-ptah-wennef is written in front of his two legs on the surface of the pedestal, while the text of the lady is inscribed on the lower rim. The text begins from right to left as follows:

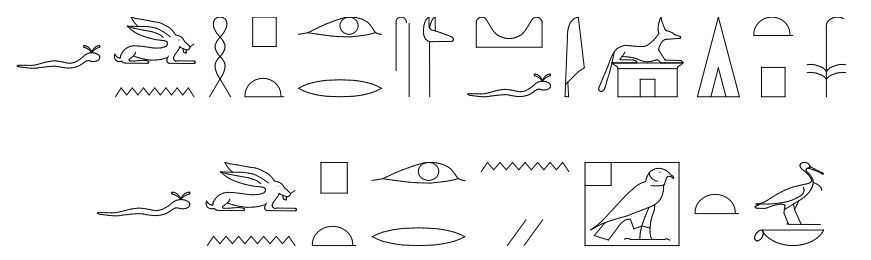

\section{[1] htp di nsw'Inpw [ tp] dww.fWsr-pth -wnn.f. [2] b3kt- $n[t]-H t-h r$ irr [wsr] Pt [h] wnn.f.}

\footnotetext{
${ }^{24}$ It is really a matter of fact that except for the dresses and the features of anatomy in the two statues, no one could easily distinguish between the two sculptures.

${ }^{25}$ This stone sculpture "L" technique with back-slab is frequently used to preserve such kind of statues from desolation review: BOTHMER, B., Egyptian Sculpture of the Late Period, The Brooklyn Museum, 1960, 19, FIGS. 35-37.

${ }^{26}$ Many of inscription signs particularly on the lower rim of the statue wrote in an inconspicuous engraving and others aren't easily legible.
} 
[1] An offering -that- the king- gives, and Anubis who is [atop] (k) his mountain Weser ${ }^{(\mathrm{l})}$-ptah-wennef ${ }^{(\mathrm{m})}$.

[2] Baket-net-Hathor ${ }^{(n)}$ whom begotten for [Weser] (-ptah-wennef ${ }^{(0)}$.

\section{C-Comment:}

(k) The hieroglyphic sign "tp" is omitted from this widely used formula which bears the characteristic type of the Old and Middle Kingdoms ${ }^{27}$.

(1) The name of Weser-ptah-wennef is commonly used from at least the Middle Kingdom ${ }^{28}$.

(m)Phonograms of the word "wsr" appear to be written in unusual combination, it is incised with a group of signs ${ }^{29}$.

(n) Two signs are mostly omitted from the commonly used title " $b 3 k t$ ". The first is the letter " $K$ " which is normally written underneath the two legs of the bird sign, and the second is the letter " $t$ " which is incised at the back of the bird sign ${ }^{30}$.

(o) Sentence syntax is apparently inaccurate and quite weak. The feminine indirect genitive " $n t$ " is wrongly inscribed with the two diagonal strokes " $y$ " instead of the letter"t" ${ }^{31}$.

Moreover, the name of Weser-ptah-wennef seems to be incorrect and incomplete, it is written without the two syllables "wsr" or "pth". Obviously, one could suggest that the narrow space on the base has virtually enforced the sculptor to omit these two syllables from the name.

\section{Conclusion:}

Study of these three significant artifacts several points could be noted: 1-As it is shown by the study, the round-topped stela of Ptah-Er-Des strongly bears a Late Period criterion: costume of the figures, and the commonly used technique of inscriptions. Theoretically, the owner of the stela could be a priest of god Osiris or one of the elites who wish Osiris

${ }^{27}$ LAPP, G., «Die Opferformel des Alten Reiches unter Berücksichtigung einiger Späterer Formen», SADIK 21, Mainz, 1986, 8-23; SMITHER, P., «The Writing of @tp-di-nsw in the Middle and New Kingdom», JEA 25, 1939, 34-44 ; BATRA, Opferformel, 8 ,15,139.

28 RANKE, PN I,1 85(13).

${ }^{29}$ Review: ERMAN, \& GRAPOW, (EDS.): Wb I,362 (11-18).

${ }^{30}$ ERMAN, \& GRAPOW, (EDS.): Wb I, 429 (5-12).

${ }^{31}$ GARDINER, A., Egyptian Grammar, $3^{\text {rd }}$ ed., Oxford, 1979, $66,86$. 
forgiveness in the netherworld. Therefore, one could offer a logical scientific suggestion that this votive stela probably came from Abydos ${ }^{32}$. 2- The limestone block definitely dates back to the reign of King Seti $1^{\text {st }}$, this fact is clearly shown from his two royal cartouches on this block. Accordingly, this definitely confirms that King Seti1st dedicated a lost New Kingdom temple for god Wepwawet at Asyut. Depending on this block besides Kahl archeological evidence, the supposed location is most likely to be somewhere at the western mountain of Mangabad ${ }^{33}$.

3- As regarding the double statue of Weser-ptah-wennef, there is no clear proof referring to its date or provenance. Nevertheless, this kind of statue was widely used from the Old Kingdom onwards ${ }^{(34)}$. The weak state of proficiency in distinguishing facial features, slightly engraved inscriptions and simplicity implementation, could urge one to believe that it could be dated to the Late Period ${ }^{35}$.

\footnotetext{
32 Review: Stewart, H., Petrie Museum: Egyptian Stelae Reliefs and Paintings: from the Petrie Collection, The Late Period, Warminster, 1993, 7-14; for more elaboration on the characteristic technique of the Late Period Stelae review, LABUDEK, J., «Late Period Stelae from Saqqara, A Socio-cultural and Religious Investigation», PhD Thesis, University of Birmingham, 2010.

${ }^{33}$ For elaboration about this assumption review: notes 9,10,11,20,21; KAHL, J., Ancient Asyut: The First Synthesis after 300 Years of Research, Wiesbaden: Harrassowitz Verlag, 2007, 3,28,52.

${ }^{34}$ BorchardT, L., Catalogue Général des Antiquités Égyptiennes du Musée du Caire: Statuen und Statuetten von Königen und Privatleuten im Museum von Kairo, Berlin, 1925, №s. 89,151,158,168-70,110,114,119.

${ }_{35}$ Mention of Hathor and Ptah in the owner's name may give a questionable indication to assume that it probably came from Memphis, but no scientific evidences are supporting this view.
} 


\section{Bibliography:}

- ALLEN, G., The Book of the Dead, or Going Forth by Day, London 1974.

- BARTA, W., «Aufbau und Bedeutung der Altagyptischen Opferformel», AgFo 24, 1968.

- Borchardt, L., Catalogue Général des Antiquités Égyptiennes du Musée du Caire: Statuen und Statuetten von Kö̈igen und Privatleuten im Museum von Kairo, Berlin, 1925.

- BothMer, B., Egyptian Sculpture of the Late Period, The Brooklyn Museum, 1960.

- BRAND, P., The Monuments of Seti 1 and Their Historical Significance: Epigraphy, Art Historical and Historical Analysis, University of Toronto, Canada 1998.

- Calverley, M., The Temple of King Sethos I at Abydos, Volume III: The Osiris Complex, London 1938.

- COLLIER, S., «The Khepresh Crown of Pharaoh», A Journal of African Studies, 21, 1-2, 1993.

- DAVIES, V., «The Origin of the Blue Crown», JEA 68, 1982.

- DuQuesne, T., «Votive Stelae for Upwawet from the Salakhana Trove», Discussions in Egyptology, 48, 2000.

- DuQuesne, T., «Hathor of Medjed», Discussions in Egyptology, 54, 2002.

- DuRISCH, N., «Culte des Canidés à Assiout: Trois Nouvelles Stèles Dédiées à Oupouaout», BIFAO 93, 1993.

- ERMAN, A., \& GRAPOW, H., (eds.): Wörterbuch der Ägyptischen Sprache, Leipzig (J. HINRICHS) $1926-1931[=W B]$.

- GARDINER, A., Egyptian Grammar, $3^{\text {rd }}$ edition, Oxford, 1979.

- GARDINER, A., Late Egyptian Stories, Bruxelles, 1932.

- GARDiner, A., Ancient Egyptian Onomastica, vol.2, Oxford, 1947.

- GAuthier, H., Dictionnaire des Noms Géographiques Contenus dans les Textes Hiéroglyphiques, Caire Société Royale de Géographie d'Égypte, vol 3, 1926.

- JANSSEN, J., Commodity Prices from the Ramessid Period, Leiden, 1975.

- KAHL, J., Ancient Asyut: The First Synthesis after 300 Years of Research, Wiesbaden: Harrassowitz Verlag, 2007.

- KAMAL, A.: «Fouilles à Deir Dronka et à Assiout», ASAE 16, 1916.

- KiTCHEN, K., Ramesside Inscriptions, Historical and Biography,1, Oxford,1975.

- LABUDEK, J., «Late Period Stelae from Saqqara, A Socio-cultural and Religious Investigation», Ph.d Thesis, University of Birmingham, 2010.

- LAPP, G.:«Die Opferformel des Alten Reiches unter Berücksichtigung einiger Späterer Formen», SADIK 21, Mainz 1986.

- LEITZ, C., Lexikon der Ägyptischen Götter und Götterbezeichnungen, Orientalia Lovaniensia Analecta 111, vol. 2, 2002.

- LESKO, L., A Dictionary of Late Egyptian, vol 1, Providence, RI: B.C. Scribe Publications, 2002.

- MonTET, P., «Les Tombeaux de Siout et de Deir Rifeh», kêmi 6, 1936. 
- RANKE, H., Die Ägyptischen Personennamen, Glückstadt, 1935.

- SMITHER, P., «The Writing of Htp-di-nsw in the Middle and New Kingdom», JEA 25, 1939.

- Stewart, H., Petrie Museum: Egyptian Stelae Reliefs and Paintings: from the Petrie Collection, The Late Period, Warminster, 1993.

- VON BeCKERATH., Handbuch der Ägyptischen Königsnamen, MÄS 20,, Mainze : P. Von Zabren 1984.

- Wells, E., «Display and Devotion: A Social and Religious Analysis of New Kingdom Votive Stelae from Asyut», UCLA Electronic Theses and Dissertations, California, 2014. 


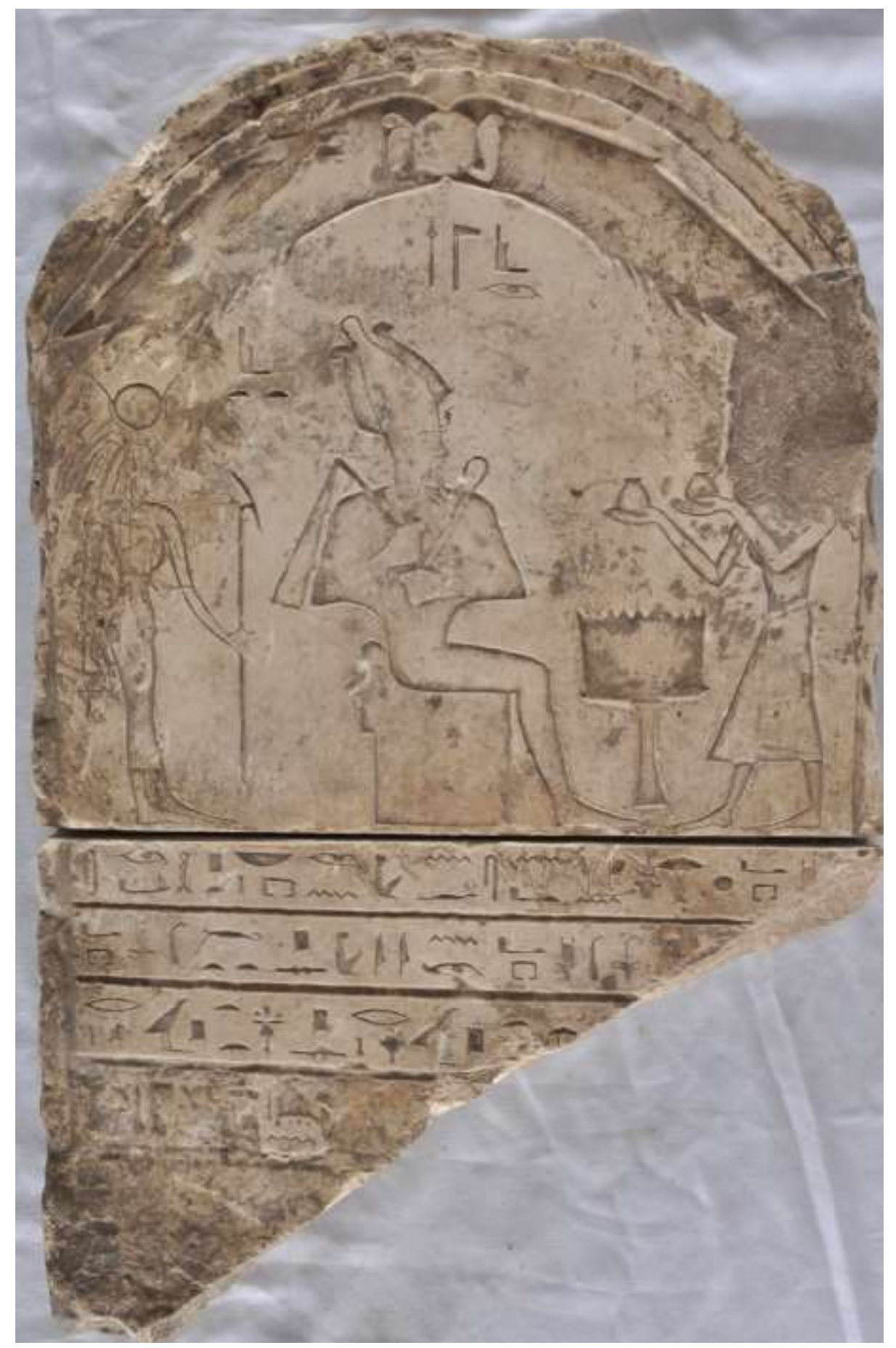

Pl.1: The votive stela of Ptah-Er-Des

Taken by the researchers 


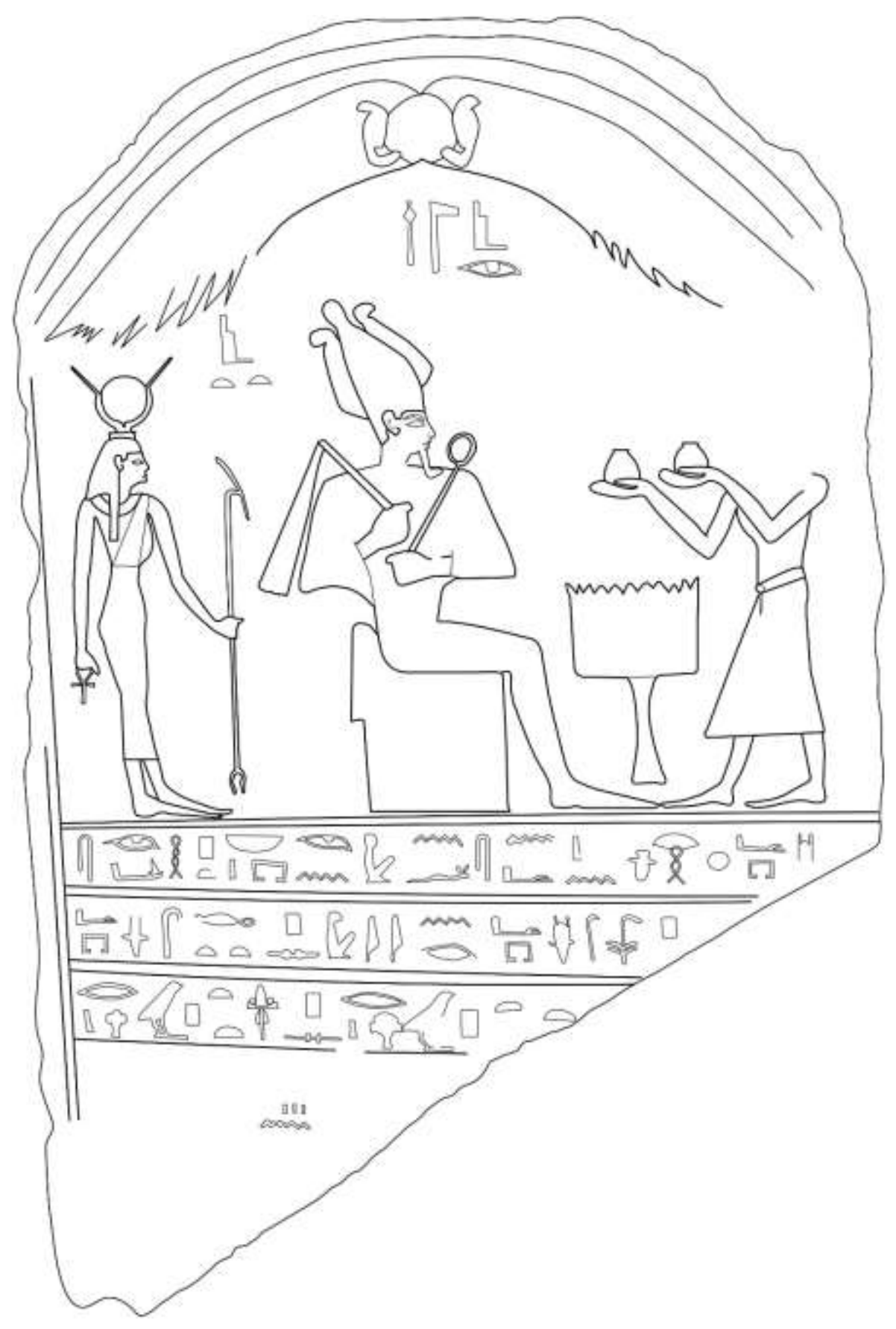

Fig.1: The votive stela of Ptah-Er-Des 


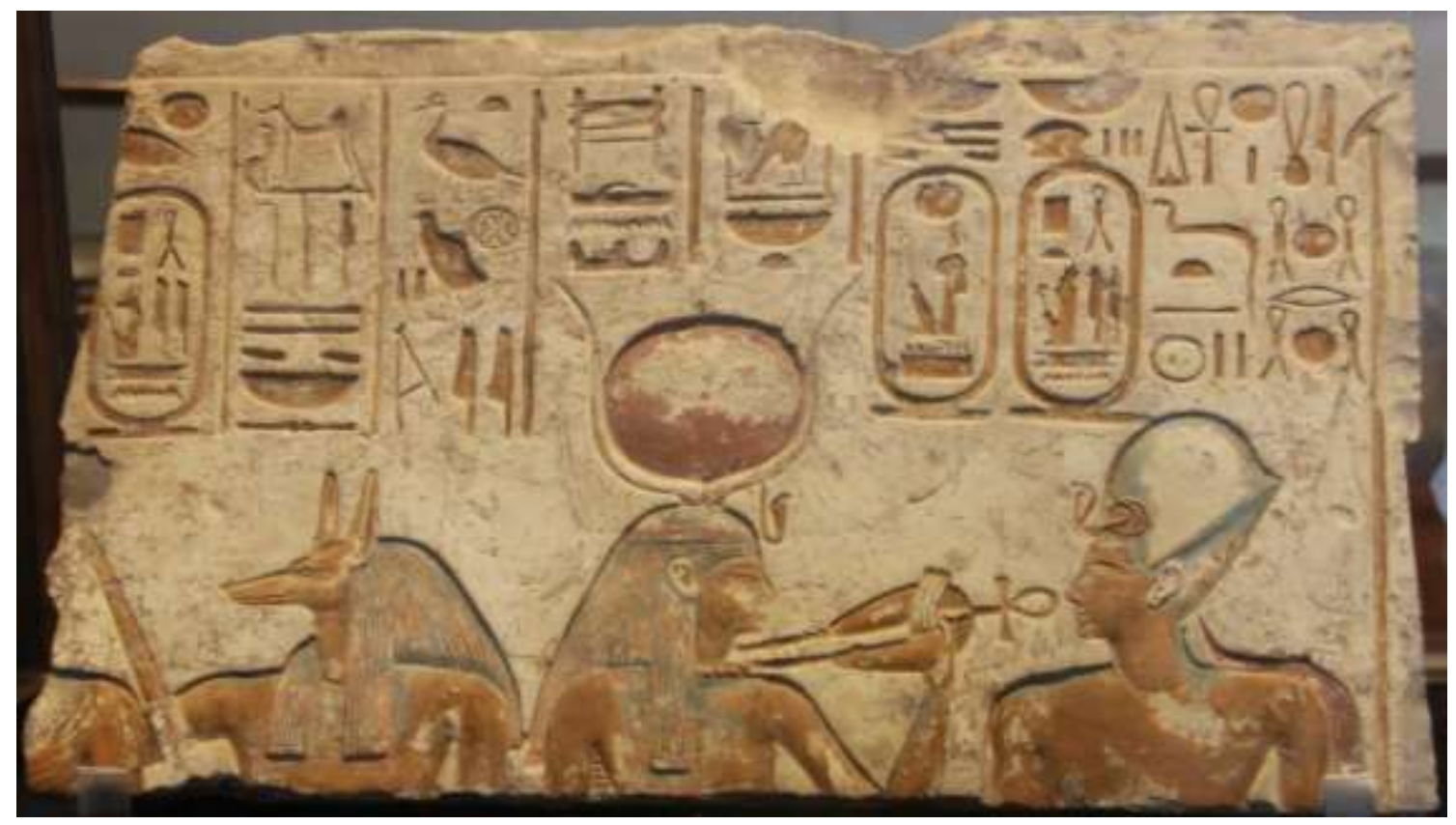

Pl.2: King Seti I's stone block

Taken by the researchers

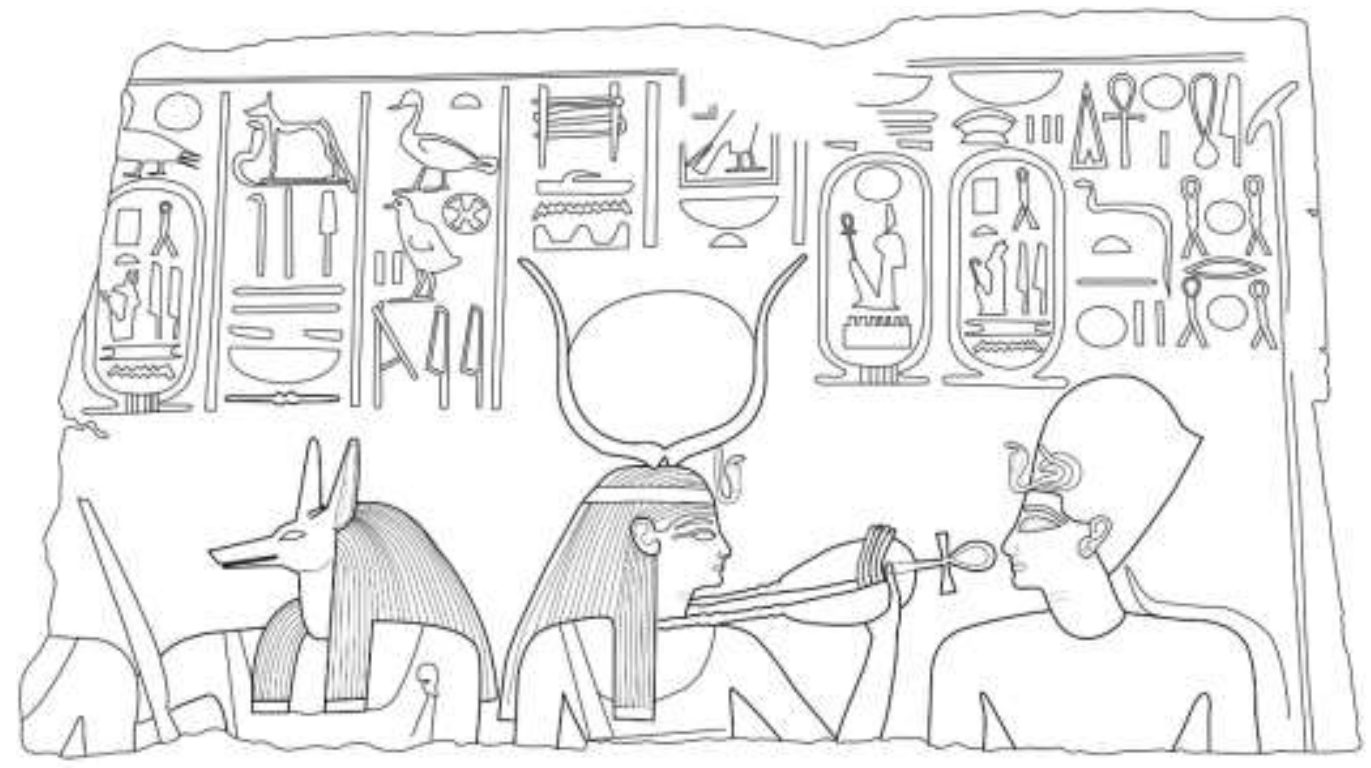

Fig.2: King Seti I's stone block 


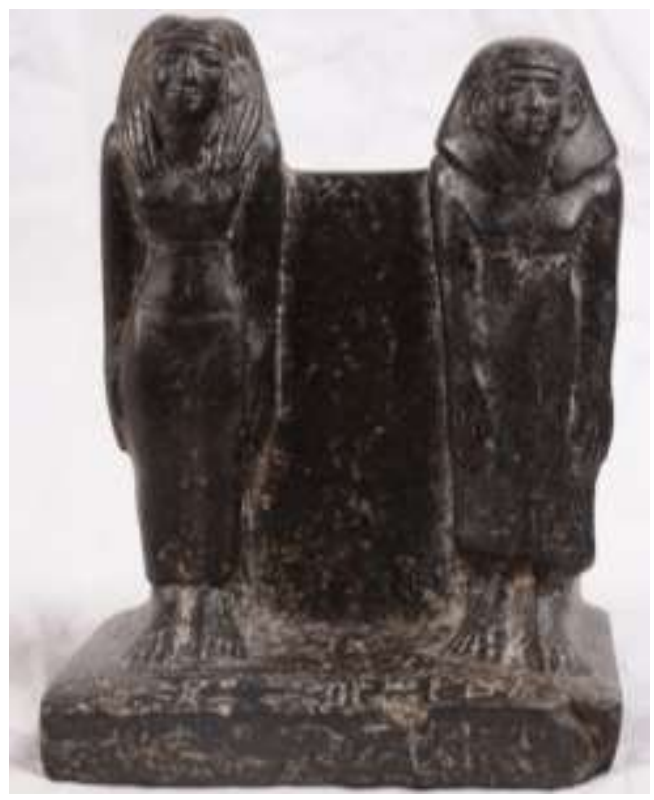

P1.3 The double Statue of Weser-ptah-wennef

Taken by the researchers

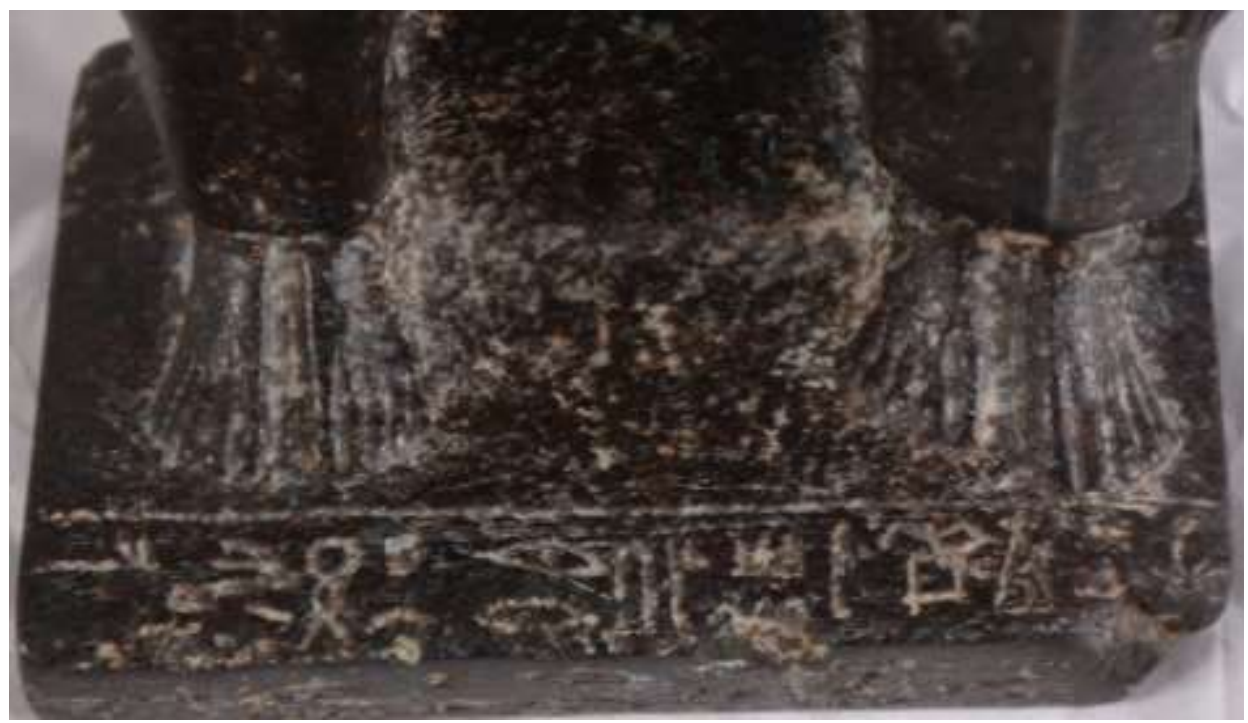

Pl.4 The text of Weser-ptah-wennef

Taken by the researchers

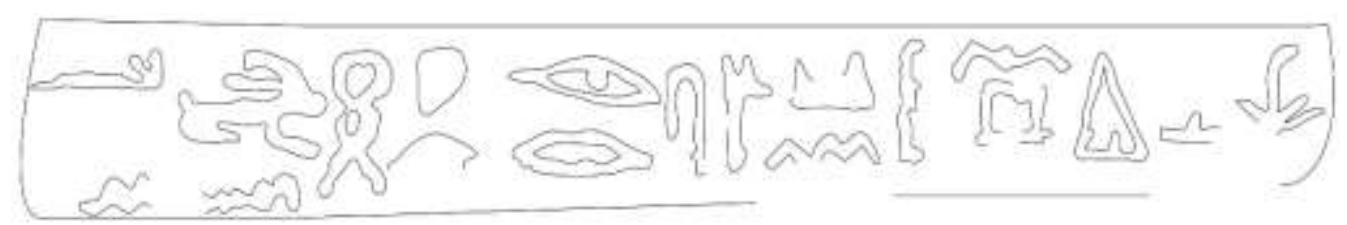

Fig.3 The text of Weser-ptah-wennef 


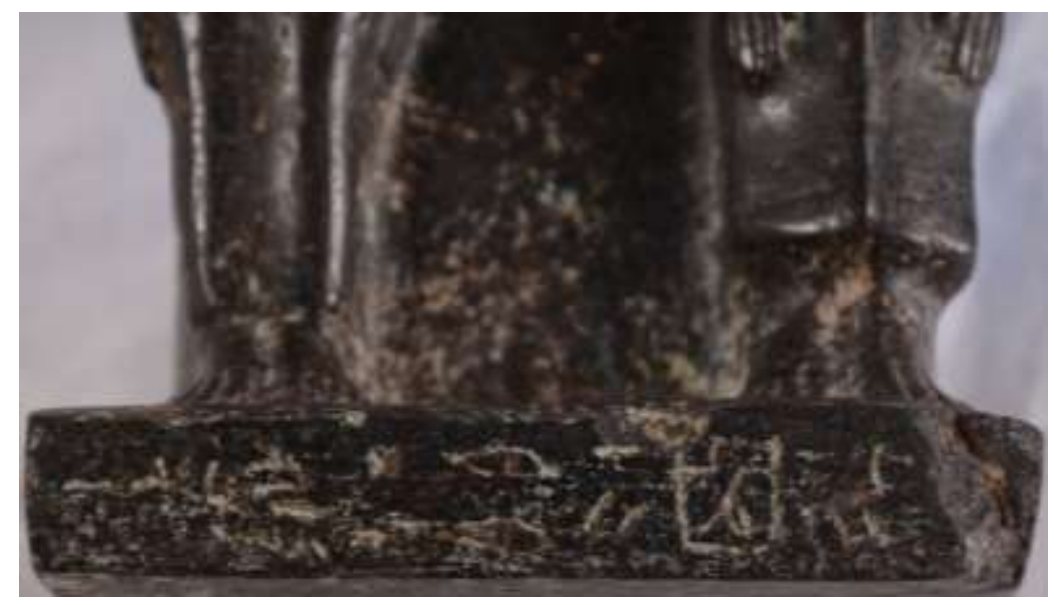

P1.5 The text of Baket Hathor on the lower rim

Taken by the researchers

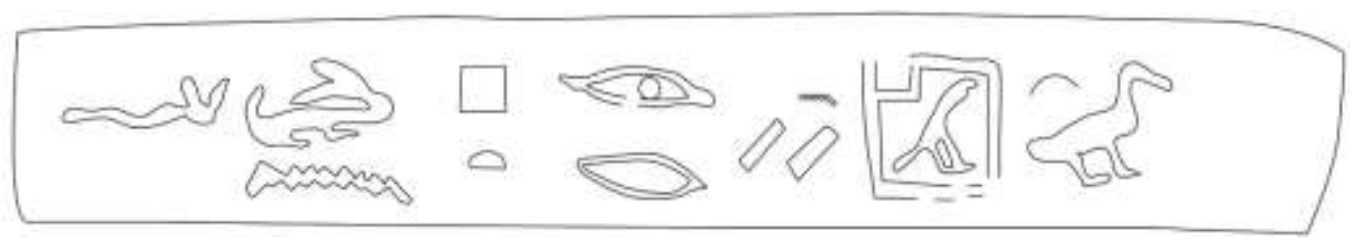

Fig.4 The text of Baket Hathor on the lower rim 